\title{
An Assessment of the Seasonal Rainfall and Its Societal Implications in Zanzibar Islands during the Season of October to December, 2019
}

\author{
K. H. Kai' ${ }^{1}$ A. L. Kijazi², S. E. Osima² \\ ${ }^{1}$ Tanzania Meteorological Authority (TMA), Kisauni, Zanzibar, Tanzania \\ ${ }^{2}$ TMA, Ubungo Plaza, Dar es Salaam, Tanzania \\ Email: kombo.kai@meteo.go.tz, kombokai68@gmail.com, agnes.kijazi@meteo.go.tz, sarah.osima@meteo.go.tz, \\ sarah.osima@gmail.com
}

How to cite this paper: Kai, K.H., Kijazi, A.L. and Osima, S.E. (2020) An Assessment of the Seasonal Rainfall and Its Societal Implications in Zanzibar Islands during the Season of October to December, 2019. Atmospheric and Climate Sciences, 10, 509-529. https://doi.org/10.4236/acs.2020.104026

Received: June 5, 2020

Accepted: September 12, 2020

Published: September 15, 2020

Copyright $\odot 2020$ by author(s) and Scientific Research Publishing Inc. This work is licensed under the Creative Commons Attribution International License (CC BY 4.0).

http://creativecommons.org/licenses/by/4.0/

\begin{abstract}
The assessment of the performance of the October to December (OND), 2019 rainfall season in Zanzibar (Unguja and Pemba) with reference to local downscaled Tanzania Meteorological Authority (TMA) forecast, and regional (Intergovernmental Authority on Development Climate Prediction and Application Center (IGAD-ICPAC) weather forecasts were assessed by comparing the long term average of OND rainfall data and previous OND rainfall seasons of 2016, 2017 and 2018 as well as extreme positive Indian Ocean Dipole (IOD) during OND seasons of 1961, 1994, 1997, 2006 and 2019 for Zanzibar. The study assessed zonal (u) and meridional (v) winds at 850 and 200 $\mathrm{mb}$, monthly and dekadal sea surface temperature (SST); the Madden Julien Oscillations (MJO) forecast reports and the ocean heat content data. Both gridded and observed datasets were processed into dekadal, monthly and seasonal averages and then analysed. The results revealed that, based on the observations, above normal rainfall of 936 and $908 \mathrm{~mm}$ were reported at stations of Kisauni (Unguja) and Karume airport (Pemba) during 2019 OND season. This amount was the first and second ever recorded for the extreme positive IOD during OND seasons of 1961, 1994, 1997, 2006 and 2019, and also the first for the previous higher OND rainfall seasons of 2016, 2017 and 2018 which was highly variable. Moreover, these values were second ever-recorded highest OND rainfall since 1916 to 2019 where the first one was observed in 1961. Furthermore, the results revealed that 2019 OND seasonal rainfall had the highest amount of contribution based on historical climatology. For instance, the 2019 OND rainfall for Kisauni, Pemba airport and Matangatuani contributed to $198 \%, 303 \%$ and $231 \%$ of the long term (1987-2016)
\end{abstract}


mean OND rainfall in Zanzibar. Indeed, the results show that the presence of the MJO during OND and the enhanced positive IOD was among the causes for the observed wetness of the 2019 OND in Zanzibar and most parts of the country. Moreover, the dominant easterly, southeasterly and northwesterly onshore winds during 2019 OND also contributed to heavy rainfall. The monthly rainfall variability among stations had the highest amount of rainfall which ranges from 400 to $500 \mathrm{~mm}$ which was observed during October in Kisauni and Karume airport, while the lowest amount ranging from 150 to $180 \mathrm{~mm}$ was observed during November in Matangatuani and the surrounding stations. Based on the comparison of the forecasted reports issued by ICPAC and TMA, the results revealed that irrespective of not considering the likelihood of occurrence of MJO and strong positive IOD both forecasts has performed well with that of ICPAC being leading. Conclusively, since the 2019 OND season has been uniquely characterized by the presence of MJO and IOD polarities it would be worthful to consider the two as input parameters during the OND rainfall forecast over the region.

\section{Keywords}

OND, Rainfall Forecast, Performance, Sea Surface Temperatures, MJO and IOD

\section{Introduction}

Zanzibar is among the East African country which largely depends on rain fed agricultural activities for economic growth and as a way to alleviate poverty. The variability of rainfall has a great impact on the agricultural planning and water resources management [1]. Climatically, Zanzibar lies under the tropical climate with two regimes of rainfall patterns i.e. long rains season of March to May (MAM) and short rains season of October to December (OND) and characterized with heavier precipitation records than on the mainland coast due to moisture convergence in sea breezes [2]. The long rain season in the islands is characterized by abundant rainfall with good temporal and spatial coverage, while during the short rain season are characterized by limited rainfall with poor spatial and temporal coverage [3] [4] [5]. Normally the short rains are associated with the northeast monsoon flow, while the long rains are dominated by southerly to southwesterly and southeasterly monsoon flow [4] [5] [6]. The seasonal and annual rainfall observed in the world (Zanzibar in particular) has resulted from Ocean/atmosphere interaction [7] [8] through exchanging mass (including gases, aerosols, sea spray, and water), momentum (through wind stress and evaporation), and energy (including heat) at the sea water and air interface i.e. atmosphere impacts the ocean mainly through the exchange of momentum, net surface heat flux and freshwater flux. For instance, reference [9] has noted that almost half of the absorbed solar energy at the sea surface is released back to the atmosphere in form of OLR. Also, reference [5] noted that the monthly and sea- 
sonal OLR over coastal Tanzania, from 1982-2011/12 was characterized by OLR deep convection cells of less than $200-250 \mathrm{Wm}^{-2}$, whereas during Tropical Cyclone (TC) the deep convection cells falls to less than $120 \mathrm{Wm}^{-2}$ and a net change of $\pm 15 \mathrm{Wm}^{-2}$ over coastal Tanzania indicating that ocean releases more energy to evaporation, resulting into deep convective clouds over areas characterised by deep OLR values [9].

The short rainfall season over the East Africa (EA) is normally affected by the influence of the positive polarity of the Indian Ocean Dipole (IOD) [10] [11] which leads to heavy rainfall over the coast of EA. IOD is an anomalous SST gradient between the western equatorial Indian Ocean $\left(50^{\circ} \mathrm{E}-70^{\circ} \mathrm{E}\right.$ and $10^{\circ} \mathrm{S}-$ $\left.10^{\circ} \mathrm{N}\right)$ and the southeastern equatorial Indian Ocean $\left(90^{\circ} \mathrm{E}-110^{\circ} \mathrm{E}\right.$ and $10^{\circ} \mathrm{S}-$ $0^{\circ} \mathrm{N}$ ). Besides, studies including [12] have shown that OND have a larger degree of interannual variability relative to climatology than have the MAM rains. Other phenomenon, which impacts OND rainfalls in Zanzibar, is the El Niño (warm ENSO) and La Nina (cold ENSO) events [13]. During the warm phase (El Niño), Zanzibar appears to be associated with above average rainfall while during La Niña Zanzibar and entire northern coastal of Tanzanian are associated with below average rainfall [13].

On the other hand, from November to March (DJFM) the climate of Zanzibar is influenced by the Southwestern Indian Ocean (SWIO) Tropical Cyclones (TCs) which either enhance or decline rainfall over the region [5] [6] [14] [15]. For instance, tropical cyclone Izilda (28 $8^{\text {th }}$ March, 2009) and Idai ( $4^{\text {th }}-21^{\text {st }}$ March, 2019) dried the entire coastal strip [5] [16], while tropical cyclone Bondo $\left(15^{\text {th }}-28^{\text {th }}\right.$ December, 2006) and Fobane $\left(5^{\text {th }}-15^{\text {th }}\right.$ February, 2014) enhance the rainfall over the entire country [5]. Over the SWIO basin TCs/TSs has a mean frequency of 4.5/2.8 per season [5] [17] and the mean daily rainfall associated to TCs/TSs over Tanzania ranged from are $2.0 \mathrm{~mm} /$ day to $6.5 \mathrm{~mm} /$ day in Tanga and Mtwara/Mbeya [5]. The seasonal long-term average maximum temperature of Zanzibar is about $33.3^{\circ} \mathrm{C}$ during December to February (DJF) and its average minimum temperature is about $29.5^{\circ} \mathrm{C}$ during June to September [5] [18]. As for November, the long-term average maximum and minimum temperature is $31.0^{\circ} \mathrm{C}$ and $22.7^{\circ} \mathrm{C}$ for Unguja and $30.9^{\circ} \mathrm{C}$ and $23.1^{\circ} \mathrm{C}$ for Pemba, while the average total rainfall is about $202.5 \mathrm{~mm}$ at Unguja and $169.29 \mathrm{~mm}$ at Pemba. As for November, the long term average maximum and minimum temperature is $31.0^{\circ} \mathrm{C}$ and $22.7^{\circ} \mathrm{C}$ for Unguja and $30.9^{\circ} \mathrm{C}$ and $23.1^{\circ} \mathrm{C}$ for Pemba, while the average total rainfall is about $202.5 \mathrm{~mm}$ and $169.29 \mathrm{~mm}$ at Unguja and Pemba [18].

\section{Regional and Local Forecasts for the 2019 0ND Seasonal Rainfall}

The regional IGAD Climate Prediction and Analysis Center (ICPAC) revealed the consensus forecast for the 2019 OND rainfall season that, Tanzania and its island states (Unguja and Pemba) to be characterized by normal to above normal rainfall (Figure 1(b)). The forecast was characterized with higher chance of wetter conditions in most of the equatorial and southern sectors including Tan- 
zania during OND [19]. Also, the forecast indicated on the increased likelihood of drier than average rainfall during September over southeastern and north-eastern Ethiopia, eastern Kenya, southern Somalia, western Tanzania and central Sudan [19]. Besides, earlier than normal onset of OND rains was forecasted across the western sector including Tanzania, Burundi, Rwanda Uganda, and western Kenya. Moreover, the likelihood of episodic rainfall events leading to flash floods over areas with increased likelihood of near to below normal rainfall was foreseen. Temperature out breaks was forecasted to be above average particularly, over eastern Tanzania, eastern Kenya, Ethiopia, Somalia, Eritrea and Sudan indicating increased likelihood of warmer conditions [19].

On the other hand, Tanzania Meteorological Authority (TMA) downscaled rainfall forecast for 2019 OND (Figure 1(a)), The results showed that Zanzibar (Unguja and Pemba) was forecasted to have normal to below normal rainfall characterised by poor spatial coverage [20], with the onset and cessation of second week of October and fourth week of December, 2019. The forecast revealed the presence of long dry spells over the northern coast areas and normal rains on the second week of November [20]. The TMA downscaled forecast was based on existence of above normal SST over the central Indian Ocean and Southwestern Indian Ocean and northwestern areas over the Somali coast during current OND which were expected to bring the offshore winds from the coastal. Also, the below normal SSTs over the southeast Atlantic Ocean (near Angola coast) were expected to decline rainfall over the northern coast (including Zanzibar) and the northeastern high lands of Tanzania, and enhance the westerly flow from Congo air mass which resulted into rainfall activities over western areas of the country [20].

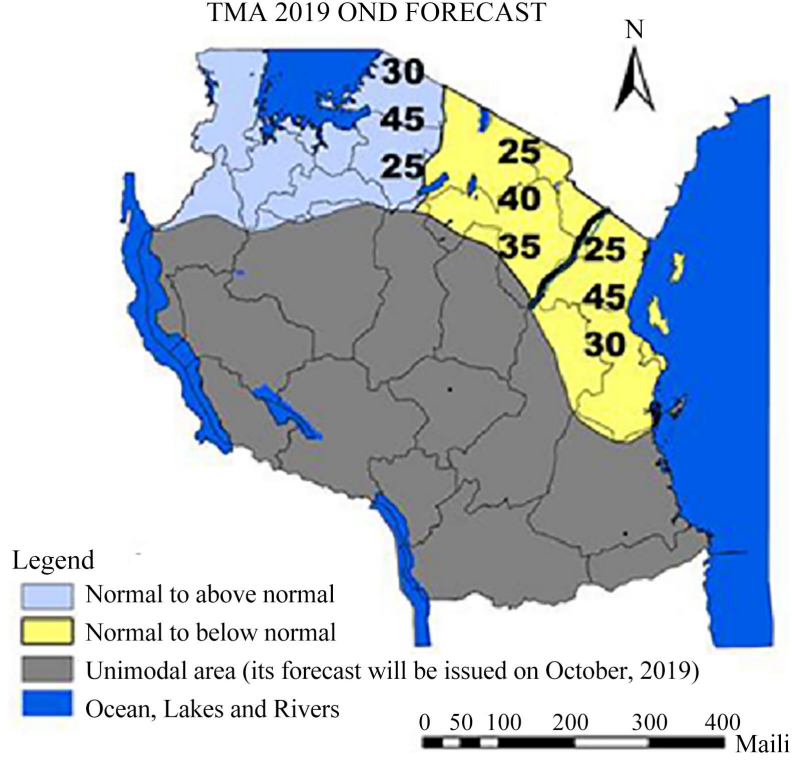

(a)

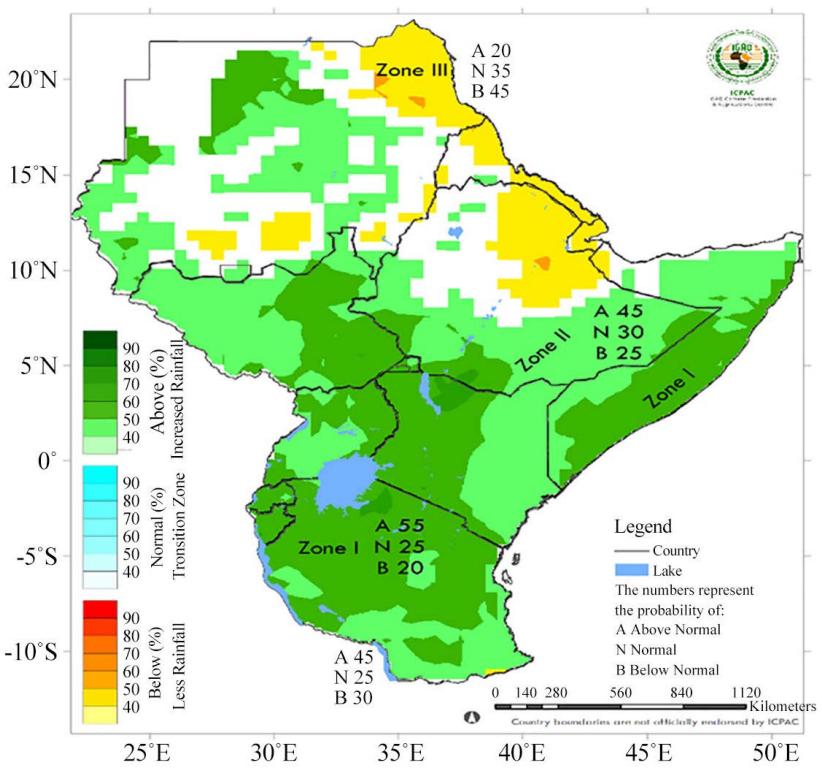

(b)

Figure 1. (a) The TMA downscaled OND, 2019 rainfall forecast (b) the ICPAC consensus on OND, 2019 rainfall forecast, Source: (ICPAC and TMA, 2019 seasonal forecasts). 
The observations and outcomes of the driving forces for the two forecasts for OND, 2019 show that in contrast to the ICPAC consensus forecast, TMA forecast did not emphasize the normal to above normal rainfall, instead it forecasted for the normal to below normal rainfall over the northern coast areas and northeastern highlands. Besides, the two forecasts did not consider the likelihood of the strong positive phase of the IOD over the southwestern Indian Ocean and strong negative phases of the IOD over Western Australia. Also, the two seasonal forecast reports [19] [20] did not consider the likelihood of the easterly flow of the phases of the Madden Julian Oscillation (MJO) where deep cloud clusters propagate eastwards in 30 - 60 days interval [21], the phenomenon which enhances the rainfall over the equatorial Indian Ocean region including Zanzibar and Tanzania at large.

Thus, this study aimed at assessing the performance of the 2019 OND rainfall season in the Islands of Zanzibar based on the past OND seasons and the regional and local forecasts issued by ICPAC and TMA, respectively. Specifically, this study aimed at understanding the driving forces of the OND 2019 season in the region, and analysing the rainfall strength (by comparing its performance with other OND seasons) and its spatial distribution during the OND, 2019.

\section{Data and Methods}

\subsection{Study Site}

Zanzibar is among the United Republic of Tanzania (URT) islands composed of two sister Islands of Unguja and Pemba, which are situated at the western Indian Ocean and are roughly defined by grid points ranging from $5.75^{\circ} \mathrm{S}-6.5^{\circ} \mathrm{S}$, and $39^{\circ} .27^{\circ} \mathrm{E}-39.53^{\circ} \mathrm{E}$ for Unguja while Pemba is roughly located at between $4.93^{\circ} \mathrm{S}$ - $5.28^{\circ} \mathrm{S}$ and between $39.67^{\circ} \mathrm{E}-39.73^{\circ} \mathrm{E}$. Politically, effective from April, 1964 Zanzibar became a semi autonomous state under the URT. Zanzibar has a population of about 1.5 million people (Census, 2015). The main economic activities of the Zanzibaries which form the pillars of its annual Gross Domestic Product (GDP) are small scale farming, fishing, business and tourism, though there are other activities which also have significant contribution to GDP like sand mining. Climatologically, Zanzibar lies under the tropical climate with two types of rainfall patterns i.e. Long rains (Masika) season of March to May (MAM) and short rains ( Vuli) season of October to December (OND). During the Masika, the islands are characterised by abundant rainfall with good temporal and spatial coverage [3] [12] [22] while during Vuli season the islands are characterised with limited rainfall, normally amount characterised with poor spatial and temporal coverage [12] [13]. Normally the short rains are associated with the northeast monsoon flow, while the long rains are dominated by southerly to southwesterly and southeasterly monsoon flow [2] [5] [11].

\subsection{Datasets}

For seeking the solutions to the aforementioned specific objectives, the study 
used the national Center for the Environmental Prediction (NCEP) reanalysis dataset for zonal ( $\mathrm{u}$ ) and meridional (v) and surface winds to assess the flow of weather systems during October to December, 2019. The extended reconstructed sea surface temperature (SSTs) anomalies were used to show the monthly positional variation of strong positive polarity of the Indian Ocean Dipole (IOD) for each month of the OND, 2019 season, also the dekadal SST variability product (and reports) was freely downloaded from the operational SST Anomaly Charts of the NOAA/NESDIS. Moreover, the MJO monitoring products were freely downloaded from Australian Bureau of Meteorology (BOM) and the Outgoing Longwave Radiation (OLR) variability for this period was obtained from NOAA CPC and NCEP. The OLR was produced from the interpolated data provided by the NOAA/OAR/ESRL and was used to forecast the Madden Julian Oscillation (MJO) status using CA model such that the OLR is often used as a way to identify tall, thick, convective rain clouds (CPC, 2019). Also, the NOAA High resolution $\left(0.25^{\circ} \times 0.25^{\circ}\right)$ optimal interpolated SST Version 2 anomalies [23] were used. Moreover, the ocean heat content data was also used; this data was used to understand which areas of the SWIO region have higher potential to ocean evaporation. Moreover, monthly and daily observed rainfall and maximum and minimum temperature records from most stations in Zanzibar was acquired from TMA offices of Unguja and Pemba airports, as well as Matangatuani agro meteorological station in Pemba. The datasets were used to feature the dekadal wind flow patterns during the 2019 OND season.

\subsection{Methods}

The zonal (u) and meridional (v) winds data was calculated into ten days average (dekad) for the months of October to December, 2019 and the vector maps were displayed and analysed to observe strong and weak convergence areas and the mean direction of the wind at 850, 500 and $200 \mathrm{mb}$ in different land (Tanzania and her neighborhoods) and oceanic (SWIO)) areas. The dekadal and monthly variability of SSTs anomalies along the SWIO region defined by $28.5^{\circ} \mathrm{E}$ to $100^{\circ} \mathrm{E}$ and $5^{\circ} \mathrm{N}$ to $40^{\circ} \mathrm{S}$ were calculated and displayed for observing the dekadal and monthly variations of the strong positive polarity of IOD. Also the dekadal variability of operational SSTs anomaly charts produced by NOAA CPC was used to observe the variation of SSTs along the SWIO region. Moreover, the monthly variability of the ocean heat content was also calculated to identify areas and direction of high heat content (low pressure and high evaporation) and low heat content (high pressure and low evaporation areas). The forecasted maps and reports of MJO and OLR developed by NOAA CPC for different phases during October to December, 2019 were used. Additionally, TMA station observation data of rainfall, maximum and minimum temperatures as well as gridded $10 \mathrm{~m}$ wind during October to December, 2019 were collected and calculated into dekadal, monthly and seasonal averages and then compared with the long-term average data. Using these averages, the station percentage contributions based on long term total or mean records were calculated. These data were used to 
quantify the influence of the aforementioned driving forces to weather of Zanzibar during 2019 OND season. Moreover, the correlations between OND rainfall with OND maximum and minimum temperatures at $\mathrm{p} \leq 0.05$ and 0.01 (95\% and $99 \%$ significant level) was conducted to observe the association between the two parameters over the region

\section{Results}

\subsection{Weather System Which Lead to Uniqueness of 2019 OND Season}

The results show the existence of MJO and strong positive IOD over the equatorial Indian Ocean and over the SWIO region, which enhanced the strength and the distribution of the OND rainfall for the first two weeks of October and weakened in the third week, and slightly strengthened in the fourth weak. The constructed analog of MJO using OLR (Figure 2 right panel) depicts a more progressive MJO event with enhanced convection shifting over the maritime continent, and suppressed convection developed across Africa and the western Indian Ocean (IO) on the second week of October, 2019, while for November, 2019 the MJO was in its weak phase over the Indian Ocean. The strong positive polarity of the IOD was still over the SWIO region which resulted into increased ocean heat content (ranged from $140-160 \mathrm{~W} / \mathrm{m}^{2}$ ) over the East African Coastal Current (EACC) areas (Figure 2 right panel), with the highest net ocean flux at the Mozambique Channel during November, 2019. On the other hand, during December, 2019 the ocean heat content remained at higher strength indicating that the channel was the warmest area of the SWIO region (Figure 2 right panel) during this season. Also Figure 2 right panel shows the progression of the heat content from east to west of the IO indicating warmer and moist conditions towards the western coast of IO.

The analysis of the NOAA operational SST anomaly for December, 2019 presented in Figure 3 (right and left panel) shows the existence of the positive IOD over Western Indian Ocean (WIO) for all three dekads of December, 2019 with the strong negative dipole over the northwestern region of Australia. The first dekad of December was characterized by warmer SST anomalies over the entire SWIO region with the highest SST anomalies over the eastern side of Madagascar, Mozambican channel and East African (EA) coast including Tanzania. This could be among the reasons which enhanced the TCs activities during early December, 2019. Similar results hold for the second dekad. As for the third dekad, the strong negative SST anomaly over the northwestern Australia picks up and shifts south westward to result in a weak dipole mimicking the neutral conditions of IOD. Irrespective of the weakening of the IOD, but still the coastal Tanzania and Zanzibar in particular were still experiencing moderate to heavy rainfall.

The analysis of the NOAA operational SST anomaly for November, 2019 presented in Figure 3 shows the existence of the positive IOD over western IO for all three dekads of November, 2019 with the strong negative dipole over the western region of Australia. 
OLR prediction of MJO-related anomalies using CA model reconstraction by RMM1 \& RMM2 (15 Dec 2019)
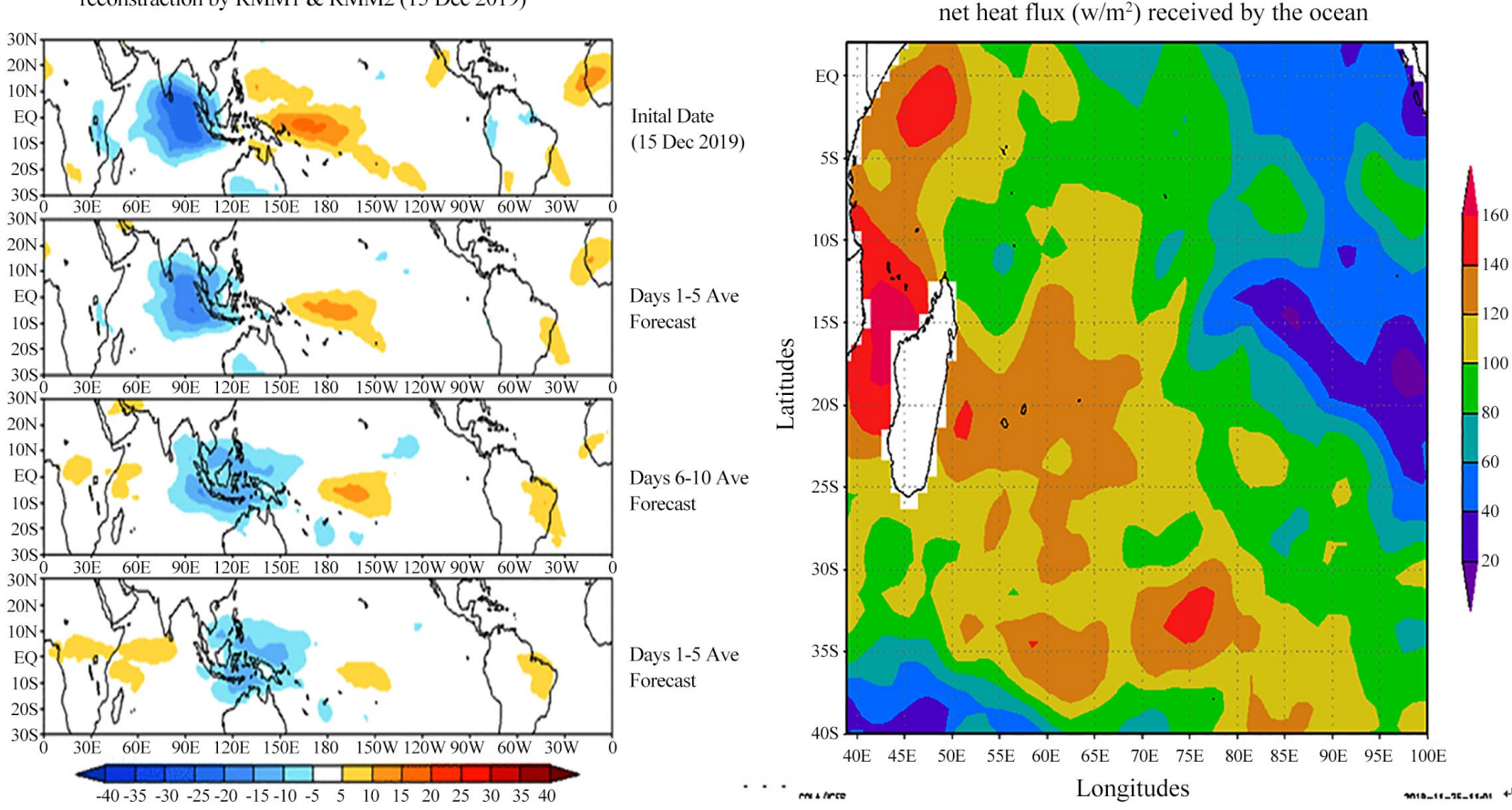

Figure 2. The OLR/MJO prediction phases (left panel); Net heat content received by the ocean $\left(\mathrm{w} / \mathrm{m}^{2}\right)$, (panel right) source (https://www.cpc.ncep.noaa.gov/products/precip/CWlink/MJO/mjo.shtml\#clivar).
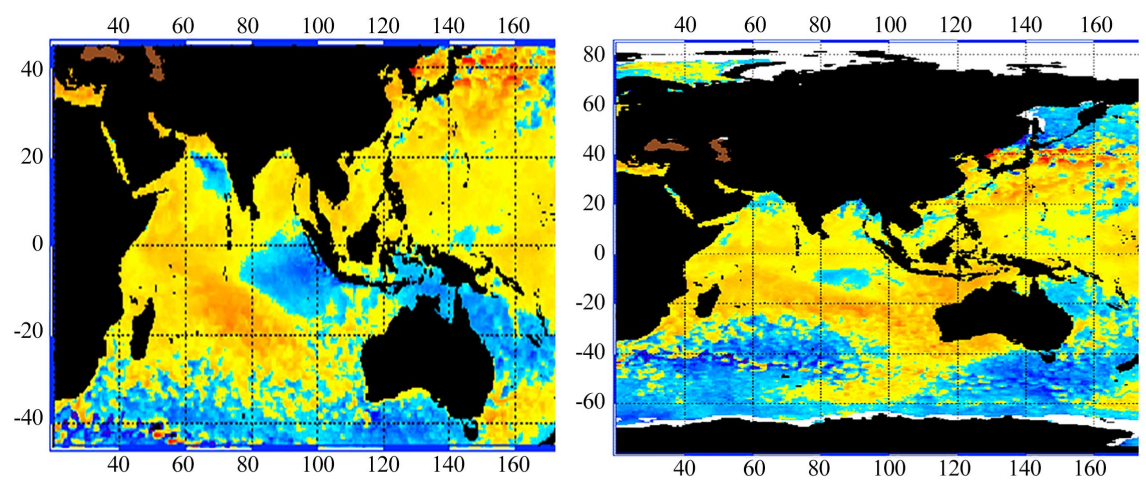

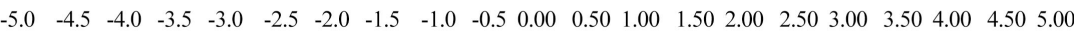

Figure 3. SST anomaly for the first dekad of November, 2019 (left panel), and third dekad of December, 2019 (right panel) (Source; edited figure of global NOAA/NESDIS SST anomaly)

The distribution of SSTs anomaly along the SWIO region and EA coast presented in Figure 4 shows that during October, 2019 (Figure 4 left panel) the SST along the coastal margin and along EACC ranged from $0^{\circ} \mathrm{C}-1^{\circ} \mathrm{C}$; and a band of high SSTs propagating towards the EA coastal waters as well as strong negative SST anomaly ranged from $-4^{\circ} \mathrm{C}$ to $0^{\circ} \mathrm{C}$ stationed over northern Australia region. This strong negative SST anomaly induced long track wind flow from deep IO to the coastal areas and hence resulted in heavy rains in most areas of Zanzibar and Tanzania at large. On the other hand, November, 2019 SST anomalies (Figure 4 
middle panel) were very strong $\left(1^{\circ} \mathrm{C}-4^{\circ} \mathrm{C}\right)$ propagated near the EA and EACC coastal waters inducing a very strong SST anomaly at the northeast Madagascar the area which is very prone to TC tracks. Also, strong negative SST anomalies over northwestern Australia were increasing its strength to reduce the strength of the dipole (i.e. reducing the SST gradients). The SST anomalies for December, 2019 Figure 4 (right panel) were characterized by reduced SST anomalies over western coast of SWIO also the reduced SST anomalies over northwestern Australia indicating the onset of neutral condition over the two wings of IOD. But the SST along the eastern Madagascar was higher $\left(>2.5^{\circ} \mathrm{C}\right)$ than an an point along the SWIO region indicating the increasing likelihood of the SWIO TCs activities.

Thus, the existence of the strong positive IOD polarity and strong SST anomalies during 2019 OND, leads to have 2 - 3 TCs activity namely Belna and Ambali (which occurred on 2nd-3rd December, 2019). One TC was tracked at the northeastern Madagascar (Belna which made landfall on the $9^{\text {th }}$ December, 2019 over northern Madagascar, bringing strong winds and rain) while the other (Ambali) was southwestward tracking at the Somali coast Figure 5 (left panel). These TCs resulted in light northeasterly winds over the coastal, light easterly over hinterlands and northwesterly over central areas of Tanzania Figure 5 (right panel). This flow resulted in moisture advection to EA region and hence resulted in moderate to heavy rainfall over the entire Tanzania, hence increasing the performance of the 2019 OND season.

The results from dekadal variability of the gridded wind vectors at $850 \mathrm{mb}$ over the SWIO region presented in Figure 6 (first raw) revealed that during the first dekad of November, 2019 (Figure 6(a)) the coastal Tanzania was dominated by strong long track southeasterly flow with slight linear convergence over the Pemba and Tanga. These winds were linearly converged over the hinterlands e.g. Morogoro, Arusha and Kilimajaro, the situation that enhanced the rainfall over these areas. Unlike the first dekad during the second dekad (Figure 6(b))
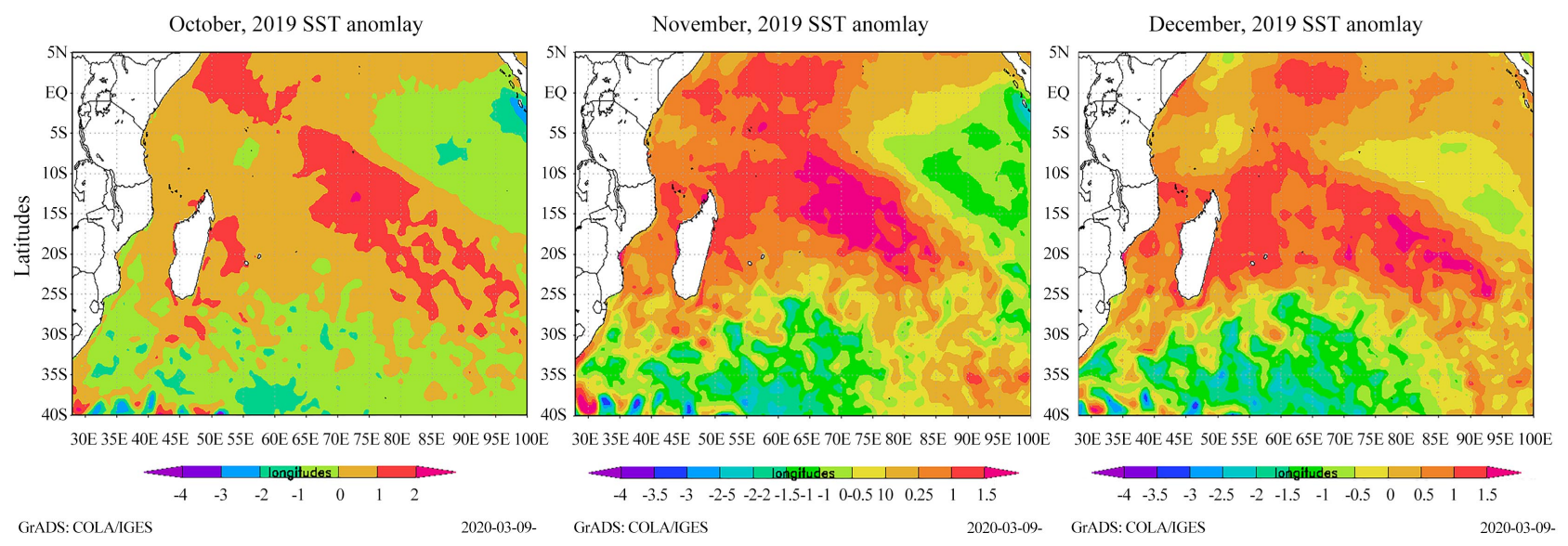

Figure 4. Monthly variability of SST anomaly during the OND, 2019 season; where the fist from left to right is the SST anomalies for October, November and December, respectively. 

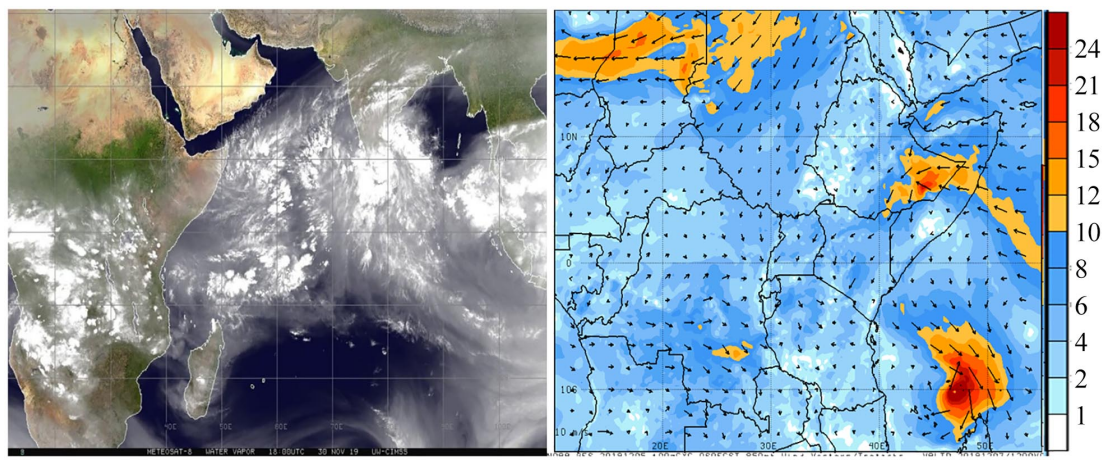

Figure 5. The twine Tropical Cyclone (TC) activities during early December, 2019 left panel and the $850 \mathrm{mb}$ wind circulation during the TCs activities right panel (Source: satellite image downloaded from https://upload.wikimedia.org/wikipedia/commons/e/ee/Ambali\%2C_Belna\%2C_and _Pawan_2019-12-06_0600Z.jpg and NCEP model forecast and Analysis (gfs_850mb_wind_eafrica.image valid at 20191207 at 1200Z).

mean $850 \mathrm{mb}$ windvector for dekade 1 Nov 2019

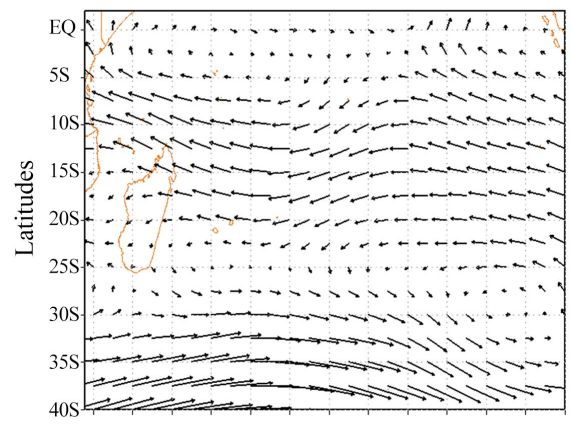

$40 \mathrm{E} 45 \mathrm{E} 50 \mathrm{E} 55 \mathrm{E} 60 \mathrm{E} 65 \mathrm{E} 70 \mathrm{E} 75 \mathrm{E} 80 \mathrm{E}$ 85 $90 \mathrm{E}$ 95E $100 \mathrm{E}$

Longitudes

DS: COLA/IGES mean $850 \mathrm{mb}$ windvector for kedade 2 Nov 2019

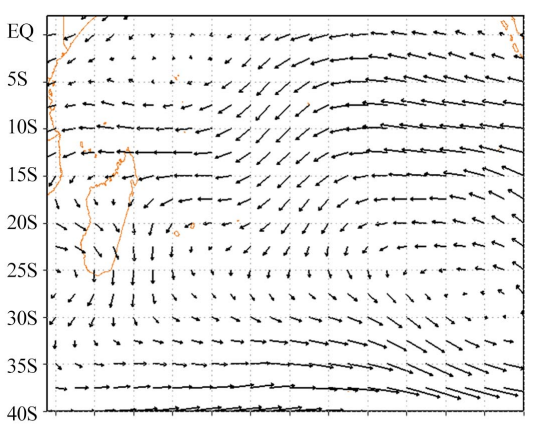

Longitudes

(b)

Dekade 2 mean 850mb wind for December 2019

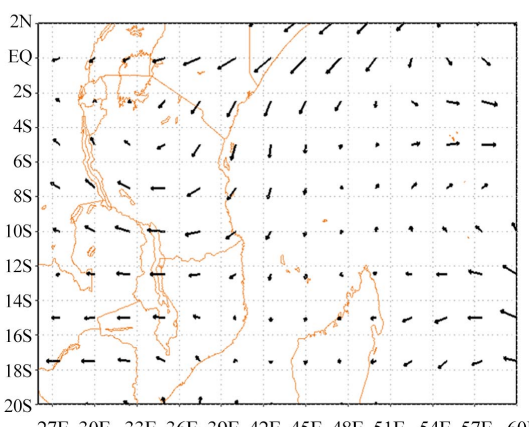

Longitudes

$\overrightarrow{7}$ 2020-01-03- COLA/IGES mean 850mb windvector for dekade 3 Nov 2019

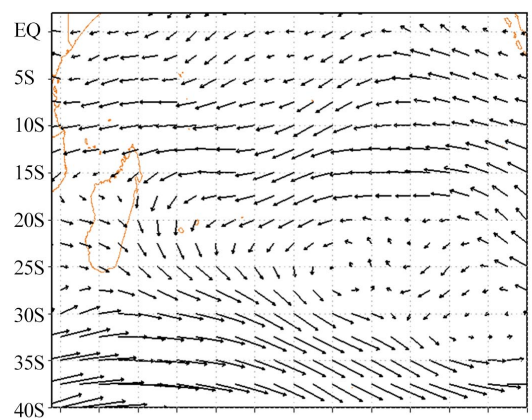

40S $40 \mathrm{E}$ 45E 50E 55E 60E 65E 70E 75E 80E 85E 90E 95E 100E

Longitudes $\overrightarrow{10} 2019$

(c)

Dekade 3 mean 850mb wind for December 2019

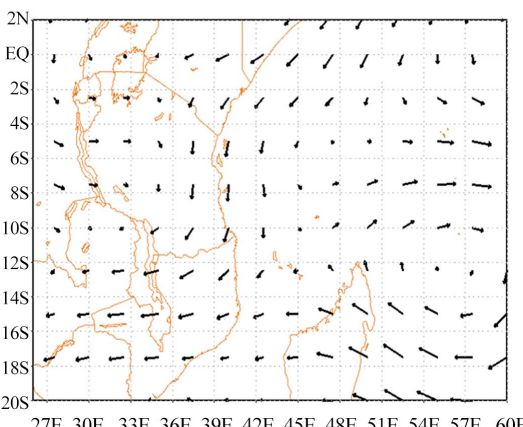

Longitudes

$\overrightarrow{9} \quad 2020-01-03$

Figure 6. The gridded $850 \mathrm{mb}$ wind for (a) the first, (b) second and (c) third Dekade of November, 2019, while (d), (e) and (f) are for the fist second and third Dekad of December, 2019, respectively. 
the $850 \mathrm{mb}$ wind flow was characterized by northeasterly flow with linear convergence over the northern coast and its hinterland areas, the situation which enhances the OND rainfall. While over the southern coast and its hinterland areas the flow was characterized by linearly converged easterly to south easterly depositing the moisture over the entire coast of Tanzania. As for the third dekad (Figure 6(c)), the $850 \mathrm{mb}$ wind flow over the coast of Tanzania was from southeasterly to easterly over the southern coast, and northeasterly over the northern coast with increased strength especially when reaching the coast, the situation which lead to reduced rainfall activities over the coastal areas.

As for three dekads of December, 2019, Figure 6 (second raw) shows the first dekad (Figure 6(d)) the coastal Tanzania was dominated by strong long track easterly flow with slight linear convergence over the northern coastal areas (Pemba and Tanga), and also over the lake zone resulting to rainfall in most parts of Tanzania including the Zanzibar Islands. This rainfall was a result of the large convergence happened over the region due to the impact of the twine cyclones existing over the region during early December 2019. As for the second dekad (Figure 6(e)) the wind flow was dominated by moderate northeasterly flow with linear convergence over the central and hinterland areas of Tanzania, the situation which enhances the 2019 OND rainfall over Lake Zone Northwestern, western and central areas of Tanzania leaving the coastal areas with reduced rainfall activities. As for the third dekad (Figure 6(f)), the long track northeasterly flow became onshore over the entire coast, and westerly flow from the Congo basin was linearly convergent to the western Tanzanian, whereas over the ocean a deep low was developed over the northeastern tip of Madagascar.

On considering the warmth of the ocean and the moisture content from different sources which enhanced the likelihood of having tropical cyclone activities, TMA issued a five days heavy rainfall and strong winds warning (i.e. effective from $27^{\text {th }}-31^{\text {st }}$ December) over some selected regions of Lindi, Mtwara, Rukwa, Mbeya, Songwe, Iringa, Njombe, Ruvuma, Dar es Salaam, Pwani and southern Morogoro (TMA, 2019). The outcome of this forecast warning was very effective for most of the forecasted areas in Tanzania.

As for the gridded $10 \mathrm{~m}$ wind during November, 2019 results presented in Figure 7 (fist raw) revealed that the first dekad (Figure 7(a)) was having strong southeasterly to southerly as it reaches the northern coast, while in second (Figure 7(b)) and third dekad (Figure 7(c)) the $10 \mathrm{~m}$ wind was linearly converged over the coastal Tanzania with easterly to south easterly orientations over the entire coast. As for the December, 2019 results presented in Figure 7 (second raw) shows that during the first dekad (Figure $7(\mathrm{~d})$ ) the ocean state over the coastal areas was having light to moderate winds with an average strength of 7 $\mathrm{m} / \mathrm{s}$ dominated by easterly to southeasterly, while the second (Figure $7(\mathrm{e})$ ) and third (Figure 7(f)) dekads were dominated by linearly converged light to moderate northeasterly onshore flow, leading to enhanced waves strengths over the ocean and discomforts for the passengers in marine vehicles. 
Dekade 1 mean 10m wind for December 2019

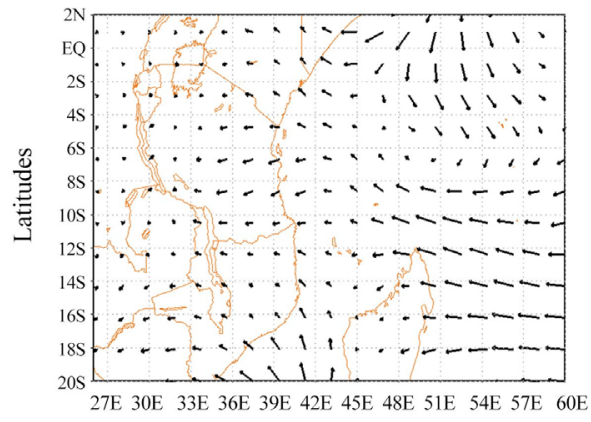

Longitudes
Dekade 2 mean 10m wind for December 2019

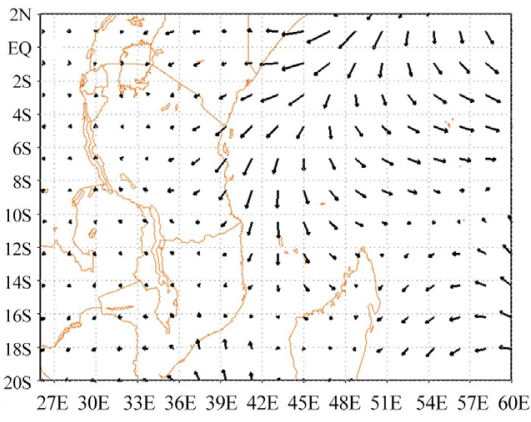

Longitudes
Dekade 3 mean 10m wind for December 2019

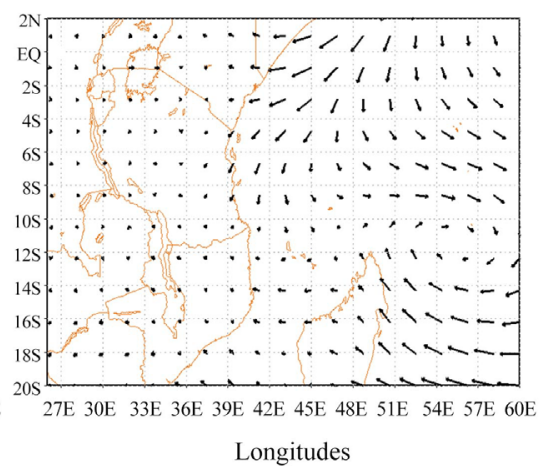

$\overrightarrow{10} \quad 2020-01-03$

GrADS: COLA/GES

$\overrightarrow{7}$ 2020-01-03-1 GrADS: COLA/IGES

7 2020-01-03-1 GrADS: COLA/IGES

(c)

(a)

Dekade 1 mean 10m wind for November 2019

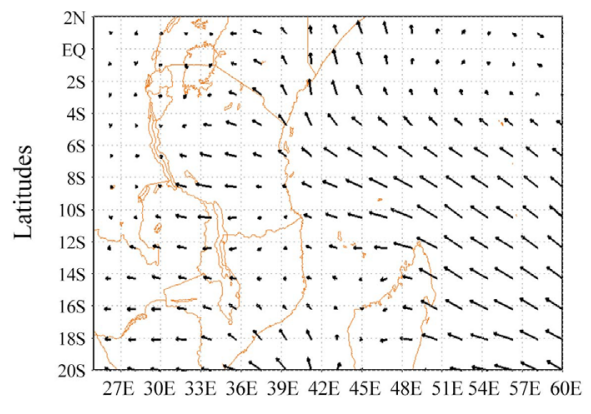

Longitudes

GrADS: COLA/GGES

9 2020-01-03 GrADS: COLA/IGES (b)

Dekade 2 mean 10m wind for November 2019

Dekade 3 mean 10m wind for November 2019

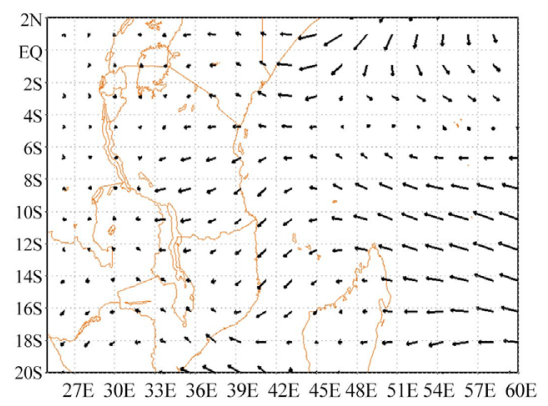

Longitudes

Longitudes

7 2020-01-03 GrADS: COLA/GES

$8 \quad 2020-01-03$

(f)

Figure 7. The gridded $10 \mathrm{~m}$ wind for (a) first, (b) second and (c) third Dekad of November, 2019 while (d), (e) and (f) are for the first, second and third Dekad of December, 2019, respectively.

\subsection{The Outcome of October, November and December, 2019 Rainfall}

In assessing the pertained weather for October, 2019 the outcome of the aforementioned weather systems presented in Figure 8 (top panel) revealed that all three dekads of October, 2019 were having rainfall of $\geq 100 \mathrm{~mm}$ with the highest amount $(227 \mathrm{~mm})$ observed at Kizimbani in the first dekad. Furthermore, rainfall was higher at Unguja than Pemba during the first dekad, while during the second dekad the distribution was nearly equal for Unguja and Pemba. Similar result holds for the monthly total rainfall which exceeded $397 \mathrm{~mm}$, with the highest downpour of $640 \mathrm{~mm}$ at Victoria Garden in Unguja. On comparing to climatology (1987-2016), the October, 2019 rainfall was $17.47 \%, 13.9 \%$ and $11 \%$ of the October long term total or $525 \%, 417 \%$ and $330 \%$ of the long term mean for Kisauni, Matangatuani and Kizimbani, respectively. Conclusively one can note that the October, 2019 rainfall for Kizimbani reveals its strength compared 
to climatology (1981-2013) as well as how strong was the onset of the, 2019 OND season.

The three dekads of November, 2019 were having rainfall ranged from 22 to $120 \mathrm{~mm}$ with the highest amount $(118 \mathrm{~mm})$ observed in Mahonda in first dekad. Similar to October, the November rainfall for all three dekads was higher at Unguja than at Pemba Figure 8 (middle panel). Moreover, Figure 8 (middle panel) reveals that stations residing along the western areas of the islands experience heavy rainfall compared to that of the eastern side of the islands. For instance, Kisauni (Unguja) and Karume airport (Pemba) both residing along the eastern side of the islands had reported a total rainfall ranged from 150 - 185 $\mathrm{mm}$, while Mahonda and Victoria (Unguja) and Matangatuani (Pemba) which resides along the western areas of the islands have reported a rainfall ranged from 200 - $260 \mathrm{~mm}$. As compared to climatology, November, 2019 rainfall was $4.2 \% 4.8 \%$ or $126 \%$ and $144 \%$ of the long term (1987-2016) total and mean rainfall for Kisauni, and Matangatuani indicating higher rainfall during October than November, 2019.
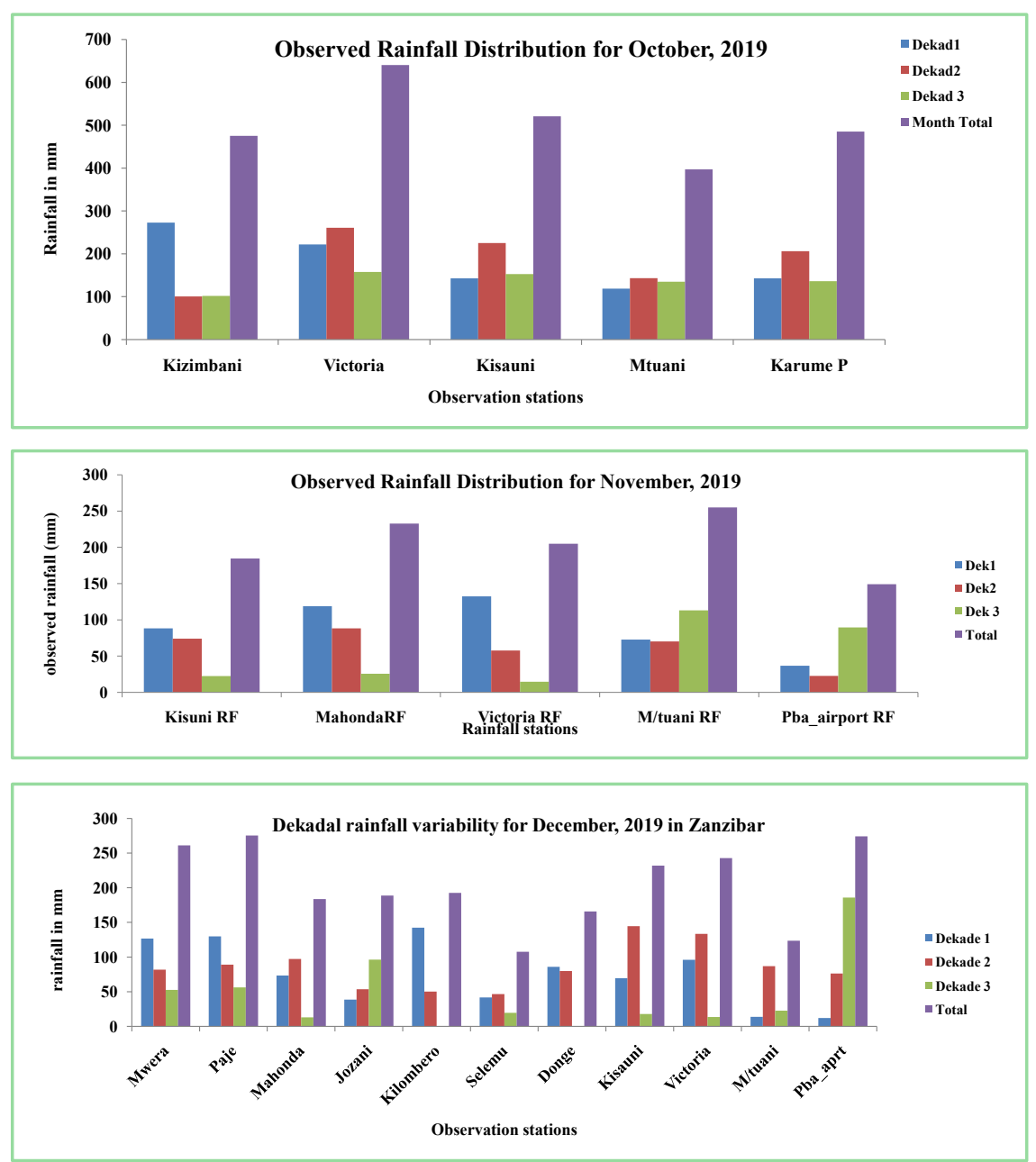

Figure 8. The dekadal rainfall distribution for October (top panel), November (bottom panel) and December 2019 (lower panel) in Zanzibar (Unguja and Pemba). 
The results of rainfall distribution presented in Figure 8 (bottom panel) shows that the three dekads of December, 2019 had rainfall ranging from 20 to $190 \mathrm{~mm}$ at all investigated stations, and during the first dekad rainfall in Unguja was higher compared to Pemba, while during the third one Karume Airport had the highest rainfall of about $186 \mathrm{~mm}$. Similar result holds for the distribution of the monthly total rainfall, which ranged from 107 to $275 \mathrm{~mm}$ with the highest downpour records in Paje and Karume airport. Unlike November, December, 2019 rainfall distribution was not affected by east west orientation, and it was $4.2 \%, 5.2 \%$ and $10.3 \%$ of the December long term (1987-2016) total rainfall or $126 \%, 156 \%$ and $301 \%$ of the December long term mean for Kisauni, Matangatuani and Karume Airport, respectively. The presented results indicate that 2019 OND rainfall was stronger compared to the previous OND records.

Generally, the analysis of the dekadal and monthly rainfall observations presented in all panels of Figure 8 for Zanzibar revealed that unlike most previous OND seasons, the 2019 OND season was marked as the second in history and being characterized by unique features of heavy rainfall and good spatial distribution country wide. Also, of the three months (October, November and December) the highest rainfall was observed in October and lowest during December.

\subsection{Maximum and Minimum Temperature Analysis}

The results of maximum and minimum temperature based on the climatology (1987-2016) show that the November, 2019 mean maximum and minimum temperatures for Unguja was higher by $0.07^{\circ} \mathrm{C}$ and $1.88^{\circ} \mathrm{C}$ to that of climatology, while the minimum temperature for Matangatuani was higher by $1.14^{\circ} \mathrm{C}$ than that of climatology. These results indicate that the current climate behaves to be warmer than the past. Also, the November, 2019 maximum and minimum temperature anomalies presented in Figure 9 (top panel) revealed the minimum temperatures are increasing at the highest rates than the maximum temperatures with that of Pemba being steeper than the rest. For instance, the minimum temperature of Pemba and Unguja show an increasing trend of $0.08^{\circ} \mathrm{C}$ and $0.06^{\circ} \mathrm{C}$ while that of maximum is $0.04^{\circ} \mathrm{C}$ (Figure 9 top panel) indicating an increased frequency of warmer nights compared to the pristine days. Based on the same climatology, the December, 2019 mean maximum and minimum temperatures for Unguja was higher by $0.04^{\circ} \mathrm{C}$ and $1.23^{\circ} \mathrm{C}$ to that of the reference climatology, while the minimum temperature for Matangatuani Pemba was higher by $0.8^{\circ} \mathrm{C}$ than that of the reference climatology. These results indicate that the current climate experience warmer nights compared to the past (1987-2016). Based on the same reference climatology, the December, 2019 maximum and minimum temperature anomalies Figure 9 (lower panel) revealed that minimum temperatures are increasing at the highest rates than the maximum with that of Pemba being steeper $\left(0.06^{\circ} \mathrm{C}\right)$ and $0.02^{\circ} \mathrm{C}$ at Matangatuani and Karume airport, while that of Unguja was $0.03^{\circ} \mathrm{C} /$ day. As for maximum temperature their trends were positive $0.002^{\circ} \mathrm{C}$ for Unguja and negative, and $-0.02^{\circ} \mathrm{C}$ in Pemba. 

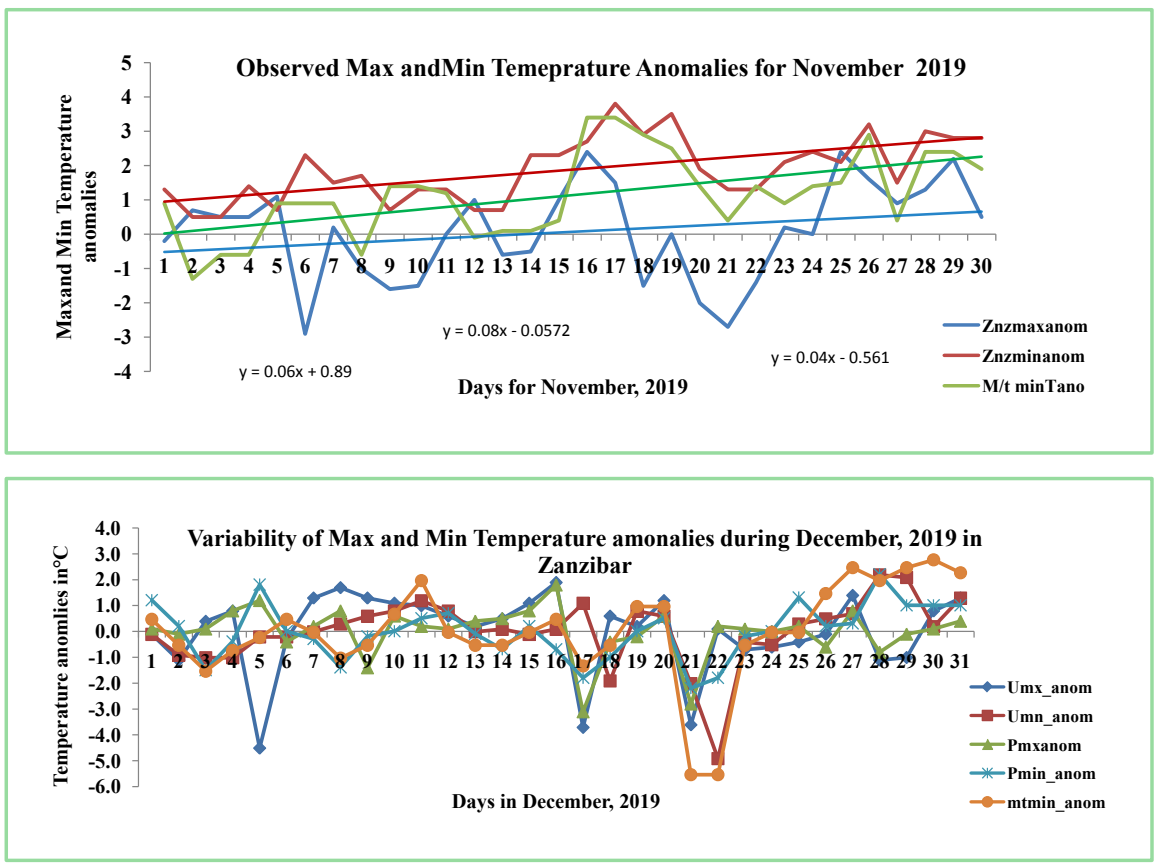

Figure 9. The daily maximum and minimum temperature distribution in Zanzibar.

Moreover, correlations between the OND rainfalls and maximum and minimum temperatures at $\mathrm{p} \leq 0.05$ and 0.01 show that rainfall at Kizimbani and Kisauni was negatively correlated with minimum temperature at $\mathrm{r}=-0.48$ and -0.28 , while the maximum temperature had weak $(r=0.24)$ positive correlation and very weak $(r=-0.1)$ negative correlation at Kizimbani and Kisauni, respectively. As for Pemba, the minimum temperature had strong negative correlation $(\mathrm{r}=-0.41)$ with OND rainfall at Matangatuani, while the maximum had strong negative correlation $(\mathrm{r}=0.66)$ at Karume airport. This indicates a decreasing rate of the maximum temperature in Pemba, which could be associated with good spatial and temporal distribution of rainfall during December 2019 (Figure 8).

\subsection{The Performance of the 2019 OND Rainfall}

The analysis of the performance of the 2019 OND rainfall was based on 1) TMA and 2) ICPAC forecasts for long term OND rainfall (1987-2016) 3) the previous three OND seasons of 2016, 2017 and 2018 and 4) the OND rainfall during the extreme positive IOD years of 1961, 1994, 1997 and 2006 for Zanzibar. The results show that rainfall distribution covered the entire region with high intensity and amount over the entire Islands. For instance, the 2019 OND rainfall for Kisauni, Pemba Airport and Matangatuani contributed to $6.6 \%, 10.1 \%$ and $7.7 \%$ or $198 \%, 303 \%$ and $231 \%$ of the long term total and mean, respectively. These results indicate that the presence of the MJO during OND, 2019 and the enhanced positive IOD for the entire season as well tropical cyclones activities for the 2019/2020 was among the causes for observed wetness of the 2019 OND particularly in Zanzibar and northern coast of Tanzania. Changing offshore winds ad- 
vect more moisture from adjoin oceanic area towards land which enhances rainfall. These onshore linearly converged winds relation to OND rainfall agrees with the previous studies [19], which noted that zonal winds show the strongest and most consistent relationships with the OND rainfall over East African; and the great role of zonal winds during wet OND periods. As for monthly rainfall comparison during the season, Figure 9 shows that October was having the highest contribution of rainfall amount ranging between $400-500 \mathrm{~mm}$, while November and December had low contribution of about 150 - $280 \mathrm{~mm}$. Moreover, Figure 9 (top panel) revealed that Kisauni and Pemba airport stations had the highest 2019 OND rainfall compared to other stations.

In comparison with the 2016, 2017 and 2018, OND rainfall for the investigated stations Figure 10 (middle panel) shows that the 2019 OND season had the highest amount of rainfall ranging from 774 to $936 \mathrm{~mm}$ compared to the previous three seasons. Also, the results of the OND rainfall variability during the extreme IOD years presented in Figure 10 (bottom panel) revealed that extreme positive IOD conditions resulted into higher rainfall over Zanzibar (Kisauni and Matangatuami) with the highest ever recorded for the last 100 years (i.e. 1916-2016), of which Matangatuani reported $1071.2 \mathrm{~mm}$ during 1961. Indeed, the presented results show that 2019 OND seasonal rainfall mimicked the 2016 OND rainfall over Pemba, indicating that 2016 could be explained as an analog year for the OND, 2019 rainfall.

On comparing the OND rainfall forecast outcomes for Zanzibar and northern coast of Tanzania the results show that irrespective of not considering the likelihood of the occurrence of the MJO and strong positive IOD, but the ICPAC consensus forecast for the northern coast (including the Zanzibar islands) was more accurate compared to the downscaled TMA forecast.

\subsection{Societal Impacts of the 2019 OND Rainfall}

The 2019 OND, rainfall was exceptional in intensity, spatial and temporal distribution. The two existing rainfall bringing mechanisms of MJO and strong positive polarity of IOD enhanced the October rainfall and resulted into number of catastrophic events. For instance, in Zanzibar town the floods associated with these rains forced significant number of people to migrate their houses, some local bridges were washed away and transportation was for some times stranded. Two peoples were reported dead with several injured at Mikunguni (area where the construction of underground water tunnel is going on). Moreover, number of ponds like Ziwa Maboga, Bint Amran among others, were flooded and hence hindering many socioeconomic activities. Some of the areas that were severely impacted in urban and town areas of Zanzibar are Ziwa Mboga, Amani sebuleni; Jang'ombe, Bint Amran among others were flooded, hence forcing the societies living nearby these areas to leave their houses. The unpublished records of the impacted societies in urban and town areas of Zanzibar collected from the Disaster Commission of the Revolutionary Government of Zanzibar $\left(\mathrm{R}_{0} \mathrm{GZ}\right)$ revealed that about 500 houses were affected, and 300 families were forced to leave 
their homes. Also, the report revealed that significant number of trees was uprooted by strong winds.

Unlike the October rainfall, which brought number of catastrophic events in Zanzibar, the November, 2019 rainfall was lower and no catastrophic events were recorded in Zanzibar. As for December, 2019 rainfall, the IOD was still having strong positive polarity over the SWIO region resulting in light easterlies to south and north westerly winds to converge over the Tanzania coastal line. Irrespective of having twine cyclones early December, but these severe events did not have strong catastrophic events, over Zanzibar but sporadic events of heavy rain and strong winds which brought significant number of damages (e.g. washing away of bridges in Morogoro, Dodoma among others) which were recorded over the country.
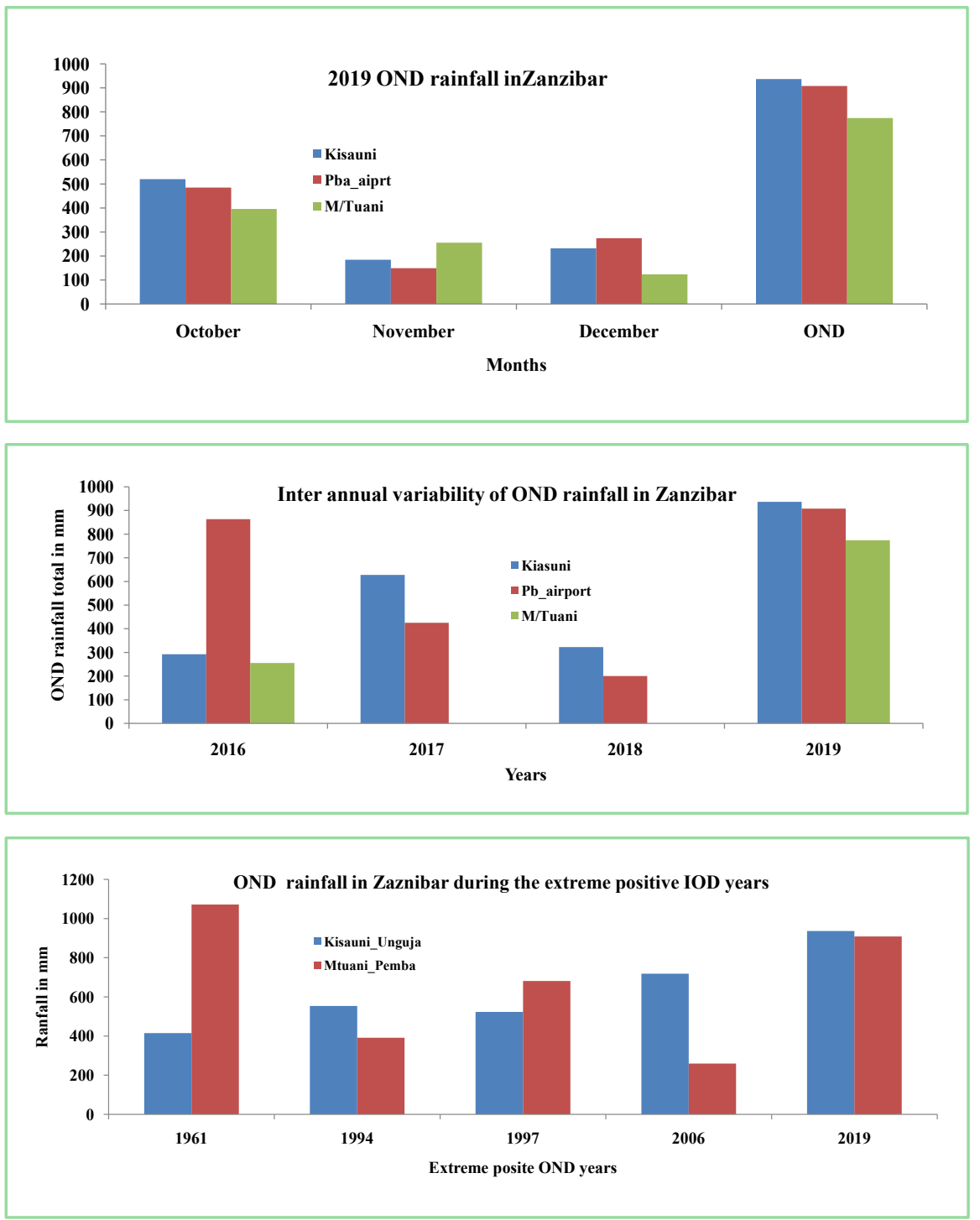

Figure 10. The OND, 2019 rainfall for some stations in Zanzibar (top panel); interannual variability of OND rainfall in Zanzibar (middle panel), and OND rainfall variability during the extreme IOD years (bottom panel). 


\section{Discussion}

Normally the northern coastal areas including Zanzibar and the northeastern highlands of Tanzania are characterized by two rainfall regimes of long rains during MAM and short rain during OND [3]. Most OND seasonal rainfall over most areas of EA is characterized by strong variability with poorly spatial distribution, weak intensity, and heavy down pool over few areas as well as late onset and early cessation. Unlike most OND seasons, the 2019 OND had been unique in spatial distribution, intensity and onset and cessation. The season was associated with well-distributed rainfall in most areas in Zanzibar and Tanzania at large. The season started as forecasted (early onset) and coincided with the 2020 MAM rainfall. The existence of strong positive polarity of IOD over the SWIO regions and equatorial African region were among the factors which marked the 2019 OND rainfall to be unique and strong over Unguja and Pemba islands due to strong moisture advection and convection from Indian Ocean as a result of increased SSTs strengths [1] [24] [25] [26]. Moreover, the study agrees with references [24] [25] and [26] where their references noted that EA OND rainfall is highly correlated with the Indian Ocean Zonal Mode (IOZM), which was derived, from the IOD indices. Furthermore, the results agreed well with the previous study, which revealed that unstable moisture advection over the eastern boundary of EA, is only during MAM and OND rainfall seasons [27]. Besides, the study finds that, the performance of 2019 OND season was enhanced by the existence of the MJO during its onset as agreed by [13]. Reference [13] noted that an early onset of MAM/OND, that early MJO peak enhances extreme wetness/dryness, while the late MJO peak corresponds to moderate dryness/wetness. Also, the high performance of 2019 OND season was enhanced by the occurrence of the early December, 2019 twine tropical cyclones activities enhanced the performance of the 2019 OND rainfall in Zanzibar and Tanzania at large. The study results had been well agreed with reference [28] which noted that days with a westerly moisture flow, bringing the Congo airmass, enhance rainfall by up to $100 \%$ above the daily mean, and these days are more likely during phases 3 and 4 of the MJO and when there are one or more tropical cyclones. The presented results had revealed that for the last short rain seasons the regional ICPAC and TMA forecast reports were significant correct based on the fact that what has been forecasted has been highly observed. For instance, presented results have shown high performance of 2019 OND compared to previous ones over different stations in Zanzibar. The performance includes the contribution of $198 \%, 303 \%$ and $231 \%$ of the long term mean OND rainfall. For specific months, the performance was $525 \%, 417 \%$ and $330 \%$ of the long term mean October rainfall, $126 \% 144 \%$ of the November long term mean, and $126 \%, 156 \%$ and $303 \%$ of the December long term mean, respectively. In comparison to specific OND seasons 2016, 2017 and 2018, the presented results have shown that OND, 2019 season had the highest amount ( $774-936 \mathrm{~mm}$ ) of rainfall compared to the previous three seasons. Indeed, the presented results show that OND, 
2019 seasonal rainfall mimicked the OND, 2016 rainfall over Pemba, indicating that 2016 could be explained as an analog year for the OND, 2019 rainfall. Furthermore, the presented results for the maximum and minimum temperatures, revealed the minimum temperature of Pemba and Unguja show an increasing trend of $0.08^{\circ} \mathrm{C} /$ day and $0.06^{\circ} \mathrm{C} /$ day respectively, while that of maximum is $0.04^{\circ} \mathrm{C} /$ day indicating an increased frequency of warmer nights compared to the pristine days. Indeed, the results have shown that due to strong negative association between the OND rainfall and temperature, the increased rainfall reduces the strength of both maximum and minimum temperatures intensity over most areas in Zanzibar.

\section{Conclusions}

The study concludes that:

1) The onset of the OND, 2019 season was peculiar to its characteristics and impacts due to weather systems (e.g. MJO and positive IOD) controlling its onset and its performance, and the season resembled that of 2006, 2008 among other, though they were not strong as the 2019 OND season.

2) The need of special consideration of research work should be conducted to understand the influence of the MJO mixed with IOD, tropical cyclones and thermodynamics of the southern Indian Ocean adjacent to Southwestern Indian Ocean (SWIO) region to the spatial and temporal distribution of OND rainfall over Tanzania.

3) The operational forecasting and research works should deeply engage with finding other inputs (factors or predictors) which can enhance the performance of the OND rainfall in Tanzania based on the onset, intensity and distribution (spatial and temporal).

\section{Acknowledgements}

The researcher would like to acknowledge the TMA and ICPAC for their seasonal 2019 OND forecast reports, but TMA administration and staff should also be acknowledged for provision of data on free of charge basis whenever requested. Indeed, I would like to thank other colleagues for their proof reading of the manuscript; otherwise all TMA staff at Zanzibar office thanked for their cooperation towards writing of this paper.

\section{Conflicts of Interest}

The authors declare no conflicts of interest regarding the publication of this paper.

\section{References}

[1] Kimani, M.W., Hoedjes, J.C.B. and Su, Z.B. (2019) Assessment of Moisture Distribution Influence on Rainfall Variability during Different Phases of IOD over East Africa. Journal of Geophysical Research Atmosphere, under Review.

[2] Mahongo, S.B. and Francis, J. (2012) Analysis of Rainfall Variations and Trends in 
Coastal Tanzania. Western Indian Ocean Journal of Marine Sciences, 11, 121-133.

[3] Kabanda, T.A. and Jury, M.R. (1999) Inter-Annual Variability of Short Rains over Northern Tanzania. Climate Research, 13, 231-241. https://doi.org/10.3354/cr013231

[4] Mpeta, E.J. (2002) Mechanisms of Inter-Annual Rainfall Variability over Tropical Highlands of Africa and Its Predictability Potential. Ph.D. Thesis, University of Zululand, $198 \mathrm{p}$.

[5] Kai, K.H. (2018) Impacts of Southwestern Indian Ocean Tropical Cyclones and Storms on the Rainfall Pattern and Vegetation Productivity over Tanzania. Thesis, the Institute of Marine Sciences of the University of Dar Es Salaam, Dar Es Salaam.

[6] Jury, M.R. and Pathack, B. (1991) A Study of Climate and Weather Variability over the Tropical Southwest Indian Ocean. Meteorology Atmospheric Physic, 47, 37-48. https://doi.org/10.1007/BF01025825

[7] Talley, L.D. (2008) Freshwater Transport Estimates and the Global Overturning Circulation: Shallow, Deep and through Flow Components. Progress in Oceanography, 78, 257-303. https://doi.org/10.1016/j.pocean.2008.05.001

[8] Reid, T.J.L. and Robbins, P.E. (2003) Data-Based Meridional Overturning Stream Functions for the Global Ocean. Journal of Climate, 16, 3213-3226. https://doi.org/10.1175/1520-0442(2003)016<3213:DMOSFT>2.0.CO;2

[9] Issufo, H. (2016) The Ocean's Role in the Hydrological Cycle. Assessment of Major Ecosystem Services from the Marine Environment. Regional State of the Coast Report; WIOMAS.

[10] Saji, N.H., Goswami, B.N., Vinayachandran, P.N. and Yamagata, T. (1999) A Dipole Mode in the Tropical Indian Ocean. Nature, 401, 360-363. http://www.nature.com https://doi.org/10.1038/43854

[11] Mahongo, S.B., Francis, J. and Osima, S.E. (2011) Wind Patterns of Coastal Tanzania Their Variability and Trends. Western Indian Ocean Journal of Marine Sciences, 10, 107-120.

[12] Hastenrath, S., Nicklis, A. and Greischar, L. (1993) Atmospheric Hydrospheric Mechanisms of Climate Anomalies in the Western Equatorial Indian Ocean. Journal of Geophysical Research, 98, 20219-20235. https://doi.org/10.1029/93JC02330

[13] Kijazi, A.L. and Reason, C.J. (2005) Relationships between Intraseasonal Rainfall Variability of Coastal Tanzania and ENSO. Theoretical and Applied Climatology, 82, 153-176. https://doi.org/10.1007/s00704-005-0129-0

[14] Jury, M.R., Pathack, B., Wang, B., Powel, M. and Nirivololona, R. (1993) Destructive Tropical Cyclone Season in the SWIO January-February 1984. South African Geographical Journal, 75, 53-59. https://doi.org/10.1080/03736245.1993.10586405

[15] Mavume, A.F., Rydberg, L., Mathieu, R. and Lutjeharms, J.R.E. (2006) Climatology and Landfall of Tropical Cyclones in the South West Indian Ocean. Western Indian Ocean Journal Marine Sciences, 8, 15-36. https://doi.org/10.4314/wiojms.v8i1.56672

[16] TMA Book (2019-2020) Statement on the Status of Tanzania Climate in 2019.

[17] Henderson, A.S., Zhang, H., Berz, G., Emanuel, K., Gray, W., Landsea, C., Holland, G., Lighthil, J., Shieh, S.-L., Webster, P. and McGuffie, K. (1998) Tropical Cyclones and Global Climate Change, a Post-IPCC Assessment. Bulletin of the American Meteorological Society, 79, 19-38. https://doi.org/10.1175/1520-0477(1998)079<0019:TCAGCC>2.0.CO;2

[18] Bakari, M.S. (2015) Climate Change Impacts and Adaptation Strategies of Small Scale Agriculture Production in Micheweni District Pemba, Tanzania. MSc Thesis, 
University of Dodoma, Dodoma University Press, Avenue.

[19] ICPAC (2019) Statement from the Fifty Third Greater Horn of Africa Climate Outlook Forum (ghacof53) for October to December, 2019 Rainfall Season: 26-28 August 2019; Hyatt Hotel, Dar es salaam, Tanzania.

[20] TMA (2019) The October to December (OND) Seasonal Forecast for Tanzania. http://www.meteo.go.tz/weather_forecasts/seasonal-weather-forecast

[21] Madden, R.A. and Julian, P.R. (1994) Observations of the 40-50 Days Tropical Oscillations. A Review. Monthly Weather Review, 122, 814-835. https://doi.org/10.1175/1520-0493(1994)122<0814:OOTDTO>2.0.CO;2

[22] Indeje, M., Semazzi, F.H.M. and Ogallo, L.J. (2000) ENSO Signals in East African Rainfall Seasons. International Journal of Climatology, 20, 19-46. https://doi.org/10.1002/(SICI)1097-0088(200001)20:1<19::AID-JOC449>3.0.CO;2-0

[23] Reynolds, R.W., Smith, T.M., Liu, C.Y., Chelton, D.B., Casey, K.S. and Schlax, M.G. (2007) Daily High-Resolution-Blended Analyses for Sea Surface Temperature. Journal of Climate, 20, 5473-5496. https://doi.org/10.1175/2007JCLI1824.1

[24] Nicholson, S.E. (2015) Long-Term Variability of the East African "Short Rains" and Its Links to Large-Scale Factors. International Journal of Climatology, 35, 3979-3990. https://doi.org/10.1002/joc.4259

[25] Kavishe, G.M. and Limbu, P.T.S. (2020) Variation of October to December Rainfall in Tanzania and Its Association with Sea Surface Temperature. Arabian Journal of Geosciences. https://doi.org/10.1007/s12517-020-05535-Z

[26] Clark, C.O., Webster, P.J. and Cole, J.E. (2002) Interdecadal Variability of the Relationship between the Indian Ocean Zonal Mode and East African Coastal Rainfall Anomalies. Journal of Climate, 19, 548-554. https://doi.org/10.1175/1520-0442(2003)016<0548:IVOTRB>2.0.CO;2

[27] Yang, W.G., Seager, R., Cane, M.A. and Lyon, B. (2015) The Annual Cycle of East African Precipitation. Journal of Climate, 28, 2385-2404. https://doi.org/10.1175/JCLI-D-14-00484.1

[28] Finney, D.L., Marsham, J.H., Walker, D.P., Birch, C.E., Woodhams, B.J., Jackson, L.S. and Hardy, S. (2019) The Effect of Westerlies on East African Rainfall and the Associated Role of Tropical Cyclones and the Madden-Julian Oscillation. Quarterly Journal of the Royal Meteorological Society, 146, 647-664. https://doi.org/10.1002/qj.3698 